\title{
Revitalization of Urban Regeneration through the Happiness Housing Project as Public Housing Policy
}

\author{
Ok-Yeon Kim ${ }^{1}$ and Jae-Pyeong Lee $^{2}$
}

(Received July 21, 2014 / Revised July 25, 2014 / Accepted July 28, 2014)

\begin{abstract}
Urban space structure in South Korea when through drastic changes ever since public housing policies began their full-fledge implementation. That is, public housing policies represent the main cause for formation of the current urban space structure, as the public houses are constructed in accordance with changes of demographic/social structure, considering changes of housing demand, in urban spaces demanded by the end users. After rapid industrialization and urbanization in the 1960's, each government in different periods have implemented housing supply policies through massive urban developments, to resolve the issue of housing shortage and residential instability. Phase 1 New Towns were developed in the 1980's resulting in suburbanization of the Seoul Area, followed by urban sprawl due to construction of small-size New Towns after deregulation in the 1990's, and construction of Phase 2 New Towns for resolution of housing shortage in the early 2000's and the resulting urban problems. In the mid-2000's, construction of Bogeumjari houses in GB areas led to insufficient housing supply in downtown areas, and the period after 2010 witnessed continuous deterioration of existing urban areas and acceleration of the rental housing crisis caused by rental housing shortage in downtown areas. Moreover, the residentially vulnerable classes consisting of young, 1 2-member households is expanding, with the real estate market in recess. Therefore, the government is trying to achieve urban regeneration through public housing policies so as to resolve the urban space problem and the housing problem at the same time, and the Happiness Housing Project has been implemented as a policy to achieve that goal. The Happiness Housing Project for young, residentially vulnerable classes in downtown areas, is going through diversification aimed at conjunction with urban regeneration projects in downtown areas, as exemplified by conversion of rental houses in residential environment improvement project districts and redevelopment/reconstruction project districts into happiness housing, and supply of happiness housing in conjunction with small reorganization projects for deteriorated residential areas in such areas as those excluded from New Town designation. Continuous supply of Happiness Housing in conjunction with urban regeneration requires mixed-use residential development which includes convenience facilities and public facilities, along with improvement of rental conditions (rental period/rent) and diversification of project methods, considering that the project is implemented in downtown areas.
\end{abstract}

Key words: The Happiness Housing, Urban Regeneration, Public Housing Policy

\section{Necessity of Discussion on Direction of Urban Development by Public Housing Policies}

\subsection{Changes of Urban Spaces by Public Housing Policies}

Housing is an important element that constitutes a city, and residential spaces are usually formed by housing supply achieved through urban development. In other words, a city mostly consists of residential areas, which means management and development of residential areas determines the shape and image of the city. Therefore, urban development can be defined as collective or massive construction of houses across the entire city. If the private sector leads the construction, the construction project is divided into small parts within the scope of the urban plan, each of which is undertaken by each constructor. If the public sector supervises the project, however, massive/collective housing sites are developed under the relevant housing policies. In the latter case, the role of the government can be classified into that of developer, supporter for suppliers and facilitator. The specific role is determined by whether the government chooses supplycentered or demand-centered housing policies, and there is possibility of policy errors due to extra-institutional influences (that is, political influences) or intra-institutional defects.

Therefore, we need to assess urban development achieved through implementation of the housing policies under previous

1) Research Fellow, Land and Housing Institute, Korea Land \& Housing Corporation, Korea (Main author: kimoy73@lh.or.kr)

2) Senior Deputy Director, Ministry of Land, Infrastructure and Transport, Korea (Corresponding author: 1jpeace@naver.com) 


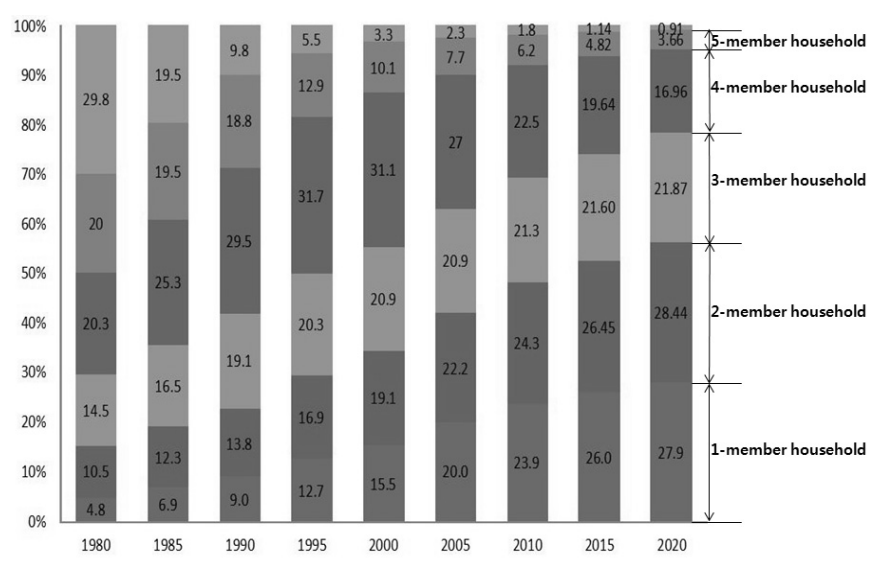

Fig. 1. Increase of 1 2-member Households Source : 2010 Census, the Statistics Korea

governments, to see how those policies affected formation of urban spaces and changes of residential environment. Based on such assessment, we need to review which direction the focus of urban development should be headed for, and which direction our urban housing policies, which greatly affect urban development, should take. In addition, since public housing policies represent the government's activities in response to housing demand changes caused by changes in the demographic and social structure, assessment of public housing policies requires review of the housing demand and the government's housing supply policies, to see how those affected the urban areas.

\subsection{Urban Structure Formed by Housing Supply in Response to Housing Demand}

Although South Korea witnessed concentration of its population into the Seoul Area and other large cities due to economic growth caused by rapid industrialization and urbanization, housing supply in those areas could not keep up with such concentration: in response, the past governments implemented supply-centered housing policies. With the housing distribution rate remaining at below $80 \%$ until the 1990's, South Korea's housing policies focused on public-led massive housing supply aimed at resolving the issue of insufficient supply and supply-demand discrepancy, while promoting housing market stability by inhibiting speculative investments.

In accordance with the Public Housing Act enacted in 1964, public-led massive developments were implemented through land readjustment project and others, under the purpose of 'promoting the people's residential stability and public welfare by supply houses to people without houses'. When rapid urbanization caused serious housing shortage in the 1970's, the government responded

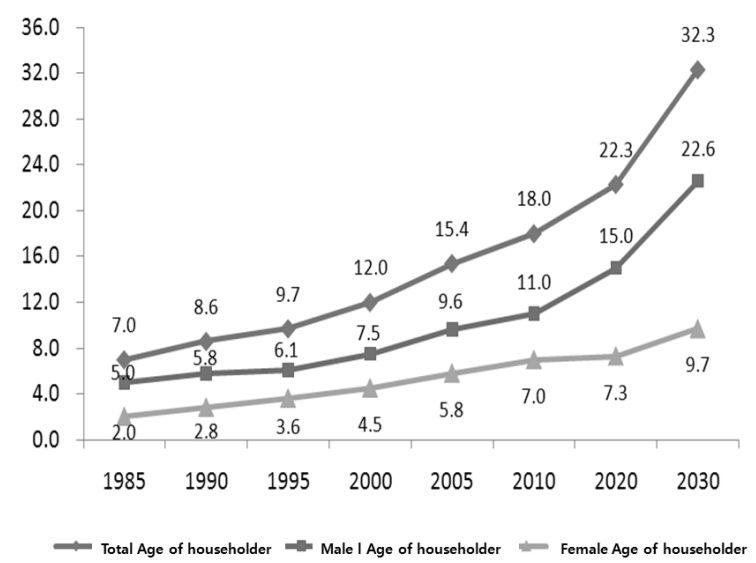

Fig. 2. Trend of Elderly Population Growth Source : 2010 Census, the Statistics Korea

by refining the system for quantitative housing supply including the Housing Construction Promotion Act (1972) and the 10-year Plan for Housing Construction (1972 1981). This policy direction, by which the government tried to resolve the supply-demand discrepancy issue through massive supply, persisted into the 1980's, with the government implementing massive 'New Town' development to solve the housing issue around the Seoul Area, as exemplified by enactment of the Housing Site Development Promotion Act (1980), and announcement of the 5 Million Housing Construction Plan (1980) and the 2 Million Housing Construction Plan (1989). Except for the 1990's when the de-regulation drive revitalized construction of small-size New Towns by the private sector, massive housing site / New Town developments continued into the 2000's, with Phase 2 New Town development implemented around cities in the Seoul Metropolitan Area (SMA) including Pangyo, Hawseong and Gwanggyo. The 'Bogeumjari Housing (Public Housing) Supply Plan' announced in 2008 estimated annual housing demand at 500 thousand, and included provision of 1.5 million public-sales houses and rental houses. Thus, housing policies focused on massive supply continued until the current government was officially inaugurated in 2013, and such development changed urban spaces: the capital area in the past has now become the Seoul Metropolitan Area (hereinafter referred to as "SMA"), through suburbanization, urban sprawl and formation of metropolitan cities, all caused by concentration of massive housing supply in the area.

Such massive housing supply is deemed to have alleviating the housing shortage, as the housing distribution rate reached $101.9 \%$ as of 2012. In particular the housing distribution rate in the capital area, where housing shortage used to be a serious issue, reached 99\%: considering the current population decrease, massive housing 
demand as in the past seems unlikely. While South Korea is still falling behind other developed countries in terms of quantitative indexes such as the number of houses per thousand persons or rental housing stock rate, it is certain that absolute housing shortage of the past is being resolved.

According to the 'Population \& Housing Census Report' announced by Statistics Korea in 2011, concentration of population into the capital area is expected to subside as population increase decelerates due to low birth rate and population aging, with the population even decreasing in Seoul by 2018. In terms of population structure, however, the number of 3 4-member households - which used to lead housing demand increase - is expected to decrease while the number of 1 2-member households is expected to increase. According to Park (2011), the percentage of 1 2-member households was only $15 \%$ in 1980 : but it reached $48 \%$ as of 2010 , and is expected to reach $56 \%$ by 2020 . Due to rapid increase of the number of aged citizens, Park estimated the percentage of aged citizens to increase from $18 \%$ in 2010 to $22 \%$ in 2020 , and $32 \%$ in 2030. Lim \& Kim (2001) found that these small-size households and aged households usually live in urban areas with good accessibility, and also prefer urban residences. Therefore, while massive housing supply is unlikely to occur after 2020 due to deceleration of population increase, retirement of the "baby boomer' generation and decrease of the age group driving the housing demand (35 54), demand for urban houses is expected to continue to increase in the near future, owing to the increase of 1 2-member households and aged households. In fact, demands for a variety of houses are actually increasing, such as residential and commercial complex, urban town house, small-size low cost houses, along with high-rise / high-density houses in some urban areas and railway station areas.

Housing policies so far failed to consider social/economic characteristics of housing demand, and focused on supplying apartments in large-scale complexes and New Town, only considering facilitation of project implementation. Even though the increase of 1 2-member households began as early as 2000 among those transferred away from their families, students and aged households, housing supply failed to these changes in characteristics of housing demand. In addition, in terms of urban areas, this failure led to concentration of new large-scale housing development projects within the $40 \mathrm{~km}$ radius from Seoul's urban center, which led to metropolitanization of the SMA and other issues such as worse traffic congestion in the SMA, increase of installation cost for metropolitan infrastructures and acceleration of deterioration of existing urban areas.
As explained above, quantitative housing issues were solved by housing supply through urban development to account for changes in housing demand, such developments caused sprawl of the SMA, which in turn caused other urban issues. The recent changes in the demographic structure warrant the need for a paradigm shift in housing policies, towards housing supply policies that consider various housing demand characteristics. These changes, as well as the increased demand for urban regeneration of deteriorating cities, require the government to shift the focus of housing supply from suburban areas to existing urban areas, while implementing housing supply through urban regeneration.

Therefore, the following sections will analyze housing supply policies and urban developments across a number of periods, and review and derive public housing policies capable of accommodating new demands for houses and urban regeneration.

\section{Analysis on Changes of Urban Development Due to Changes of Housing Supply Policies}

The process of urban growth in the capital area is closely related with public-led urban development policies of the country. The original urban areas rapidly waned due to New Town development projects led by the State to achieve rapid housing supply, with the original communities therein destroyed by redevelopment projects bent on gaining development profits.

In the Western Societies, suburbanization is described as spontaneous spatial re-arrangement due to advent of automobiles and capital changes, rather than results of policy implementations. To be specific, suburbanization led by high-income classes who can afford high transportation/residential cost resulted in highquality residential areas in the suburban areas, which caused low-income classes flocking into urban areas, causing serious deterioration such as increase of slums, vandalism and ghettos. Compared with such deterioration, South Korean cities demonstrate starkly different pattern of deterioration.

Suburbanization in the course of urban growth in South Korea took the form of planned/collective relocation of residential areas to suburban areas through state policies, rather than autonomous choice by stakeholders with shared interests such as developers and land owners. That is, the State selectively developed suburban areas before spontaneous deterioration of the urban areas took place.

Such massive development of the suburban areas resulted in rapid deterioration of the commercial sphere in the urban areas due to population outflow therefrom, as the projects were implemented with their sole focus on housing supply, failing to consider the 
functional relationship with the existing cities. Such deterioration was followed by gradual decrease of land prices.

Such planned/collective suburbanization policies by the government (candidate sites with low land prices, available for massive urban development for housing supply, were mostly in the suburban areas) worsened housing shortage in the urban areas and the areas nearby. In addition, redevelopment/reconstruction projects, which provide house in the urban areas, were stalled by various regulations (imposition of 'development charges', etc.) reinforced across a number of governments, as well as recess of the real estate market.

In addition, a number of factors decreased the demand for new development projects in suburban areas, and caused many smallsized households (including low-income class) to return to urban areas (in hopes of saving transportation cost by living in proximity of their workplaces): (1) changes in demographic/household structure in urban areas, such as increase of 1 2-member households and aging of the population, (2) social/economic changes such as deceleration of economic growth as South Korea enters the 'Low-growth Period', deceleration of household income increase and decrease of household consumption (3) increase of economically active population (15 64), household consisting of people of age 65 or above and 1-member households. These changes raised the

Table 1. Key Housing Policies across Governments

\begin{tabular}{|c|c|c|c|}
\hline \multirow{2}{*}{ Governments } & \multirow{2}{*}{ Key Housing Policies } & \multicolumn{2}{|c|}{$\begin{array}{c}\text { Housing } \\
\text { Construction }\end{array}$} \\
\hline & & Total & $\begin{array}{l}\text { Public } \\
\text { Sector }\end{array}$ \\
\hline $\begin{array}{c}\text { Rho, Tae-woo } \\
\text { ('88 '92) }\end{array}$ & $\begin{array}{l}\text { - } 2 \text { Million Housing Construction Plan } \\
\text { - Phase } 1 \text { New Town, Permanent } \\
\text { Rental Houses }\end{array}$ & $\begin{array}{c}273.7 \\
(100.0)\end{array}$ & $\begin{array}{c}92.4 \\
(33.8)\end{array}$ \\
\hline $\begin{array}{l}\text { Kim, } \\
\text { Young-sam } \\
\text { ('93 '97) }\end{array}$ & $\begin{array}{l}\text { - Private-led housing supply, } \\
\text { small-size New Towns } \\
\text { - 5/50-year public rental houses }\end{array}$ & $\begin{array}{c}312.6 \\
(100.0)\end{array}$ & $\begin{array}{l}116.5 \\
(37.3)\end{array}$ \\
\hline $\begin{array}{c}\text { Kim, Dae-jung } \\
\text { ('98 '02) } \\
\end{array}$ & $\begin{array}{l}\text { - Deregulation after IMF Crisis } \\
\text { - National Rental Houses }\end{array}$ & $\begin{array}{c}234.1 \\
(100.0) \\
\end{array}$ & $\begin{array}{r}67.4 \\
(28.8) \\
\end{array}$ \\
\hline $\begin{array}{l}\text { Rho, } \\
\text { Moo-hyun } \\
\text { ('03 '07) }\end{array}$ & $\begin{array}{l}\text { - } 1 \text { Million National Rental Housing } \\
\text { Supply Plan } \\
\text { - Phase } 2 \text { New Towns, 10-year Public } \\
\text { Rental Houses, Purchased Rental } \\
\text { Houses / Leased Rental Houses }\end{array}$ & $\begin{array}{c}253.8 \\
(100.0)\end{array}$ & $\begin{array}{c}68.6 \\
(27.0)\end{array}$ \\
\hline $\begin{array}{l}\text { Lee, } \\
\text { Myung-bak } \\
\text { ('08 '12) }\end{array}$ & $\begin{array}{l}\text { - } 1.5 \text { Million Bogeumjari Housing } \\
\text { Supply Plan } \\
\text { - Resumed Permanent Rental Houses }\end{array}$ & $\begin{array}{c}168.9 \\
(100.0)\end{array}$ & $\begin{array}{c}56.3 \\
(33.3)\end{array}$ \\
\hline $\begin{array}{l}\text { Park, Geun-hye } \\
\quad(' 12 \sim ' 16)\end{array}$ & $\begin{array}{l}\text { - Reduced Bogeumjari Housing } \\
\text { supply and expanded rental housing } \\
\text { supply } \\
\text { - Happiness Housing Project (140 } \\
\text { thousand houses to be supplied) }\end{array}$ & & 51 \\
\hline
\end{tabular}

demand for lands in urban areas for such purposes as multipurpose development, which warrants the need for changes in housing demand patterns and urban development patterns.

Furthermore, as of 2013, recess of the real estate market, along with changes in demographic/social structure, social/economic circumstances and spatial changes in land demands have caused instabilities in the rental housing market, which had grave effects on residential stability for South Koreans. In response, the government announced a plan to supply Public Rental Houses in state-owned lands in urban areas such as railroad sites, under the motto of the 'Era of the People's Happiness.' The project is currently being implemented in 7 pilot districts.

The following sections explore the government housing policies and the progress of urban development across a number of periods, which were implemented as a way to supply houses, to solve the housing shortage and residential instability of low-income classes due to rapid industrialization after the 1960's. Also, they describe the situations leading up to creation of the need for construction of happiness housing in urban areas.

Lastly, this study will introduce the concept, progress and future development of Happiness Housing Policy as a public housing policy planned and to be implemented by the current government.

\subsection{Phase 1 New Towns and Housing Supply in the 1980's: Suburbanization}

The 1980's was a period when population flocked into urban areas along with various facilities, which led to increase of production and consumption, as well as establishment of the basis for the urban economy.

Into the 1980's, urbanization expanded to suburban areas. Urban policies at the time responded by tyring to solve urban problems caused by extensive urbanization and systematically managing population distribution through construction of New Towns, etc.

Redevelopment projects such as urban redevelopment and redevelopment of poor residential areas began their full implementation, along with urban management policies such as reorganization projects for the Seoul Area.

In this period, the public ownership of land, countermeasures against speculative real estate investment and plans for residential stability of low-income classes came under the highlight, as such issues - speculative investment, housing price explosion, rent increase and concentration of land ownership - became serious political and social issues. 
In the late 1980's the government established the 2 Million Housing Construction Plan, which included housing supply for 5 New Towns in the capital area (Phase 1). The Housing Site Development Promotion Act was enacted at this time, which employed the expropriation method for its implementation.

Due to the Green Belt (GB) regulation around Seoul, development of the 5 New Towns in the capital area targeted the suburban areas beyond GB. This leapfrog development accelerated suburbanization of the capital area.

The Phase 1 New Towns in the capital area are located within $20 \mathrm{~km}$ radius from the Seoul center, and have been developed into residence-centered cities offering comfortable living environments.

In particular, Bundang, one of the $5 \mathrm{New}$ Towns located within $25 \mathrm{~km}$ southeast from the urban center and $10 \mathrm{~km}$ from Gangdong-gu and Gangnam-gu, was developed before the employment center of Seoul could be relocated, and thus the self-supply capability of the city came under much suspicion despite its location and large population $(390,000)$.

There were not enough infrastructure to accommodate the increase of traffic volume to or from Seoul, which increased the time required for commuting between the New Towns, and Seoul's employment centers, while worsening the traffic congestion problem. In addition, the increase of commuting time resulted in various legal issues such as increased transportation cost, worse pollution and reduced free time, etc.

\subsection{Small-size New Towns and Uncontrolled Development by Deregulation in the 1990's: Urban Sprawl}

The 1990's went through urban sprawl caused by de-regulation and various resulting issues, which were met with strong movements to preserve natural environments in urban and suburban areas. That is, urban sprawl spread from quasi-agricultural lands around urban areas, destroying the national lands and causing environmental crises, which brought much attention to resolving environmental issues. This was caused by deregulation on housing sales price to promote housing construction, followed by permission of housing site development by private constructors on quasi-agricultural lands. For such deregulation, the National Land Use Management Act was revised to reorganize the existing 10 use zones into 5 use zones, and greatly lifted restriction on use of rural areas by companies and local residents by designating quasi-agricultural areas. In those quasi-agricultural areas, development not exceeding 30 thousand $\mathrm{m}^{2}$ was permitted, and the upper limit of floor area ratio was increased to $400 \%$, to the same level as residential areas in the urban areas.
Balance between development and preservation is imperative for quasi-agricultural lands. However, the actual quasi-agricultural areas were subject to urban sprawl and utilization due to virtual abolishment of regulation on land use/development therein. In particular, as expansion of Phase 1 New Towns became serious social issue at this time, many small-size New Towns, alone apartments and medium/small-size factories were constructed in quasi-agricultural areas, causing urban sprawl.

Construction of small-size high-rise apartment complexes in quasi-agricultural areas was criticized for damaging the rural landscape and lowering the efficiency of land use.

The ideal pattern of development would involve construction of high-rise/high-density buildings in existing urban areas and construction of low-rise/low-density buildings in quasi-agricultural areas. However, the actual housing construction by private construction companies took the form of building small-size/ high-rise apartment complexes in suburban areas. In particular, construction of small-size New Towns increased the social cost generated by infrastructure deficiency and traffic issues while damaging the rural landscape, as those New Towns were not required to meet the infrastructure requirements applicable to large-size New Towns.

These circumstances in the 1990's laid the ground work for various attempts requiring paradigm shift for urban development in the future. Alternative paradigms began to surface against growth-centered urban policies in the past, including sustainable urban development, urban policy established through civil participation and urban planning focused on securing the public nature of development.

\subsection{Phase 2 New Towns and Expansion of the Seoul Area in the early 2000's: Seoul Metropolitan Area}

Small-size New Towns developed in the 1990's mostly ranged from 330 thousand $\mathrm{m}^{2}$ to 992 thousand $\mathrm{m}^{2}$. These New Towns were developed without adequate urban infrastructure, on sites in non-urban areas chosen only on the basis of availability for housing site development. Thus, these towns lacked self-sustaining capabilities, and later deteriorated into mere 'bed downs.' This led to serious urban problems, in terms of both urban spaces and residential environment.

As urban sprawl of small-size New Towns surfaced as a major social issue, the government announced the 'Comprehensive Plan for Prevention of Uncontrolled Land Development' in 2002, and enacted the Act on Planning and Use of National Lands' by combining the Urban Planning Act and the National Land Use 
Act, in order to implement development of quasi-agricultural areas under plans established for each district. These drastic reforms were aimed at ensuring implementation of urban development according to pre-established plans, while securing adequate infrastructures for housing sites developed in non-urban areas.

Subsequently, under the 'plan-first, development-later' principle, the government began to ensure that all urban and non-urban developments are preceded by appropriate planning.

As the small-size New Town caused various social issues and residential instability grew worse due to rapid increase of housing sales price, the government announced a new plan for massive New Town development akin to the Phase 1 New Towns (Phase 2 New Towns).

In order to supplement the inadequate housing supply caused by private-led development in the 1990's, the government partially lifted GBs for National Rental Housing supply.

Construction of National Rental Houses in GB areas was aimed at providing low-priced houses to improve reidential stability for low-income classes. In particular, the GB areas selected for the project was those with low land prices that are close to Seoul's employment centers.

Development of Phase 2 New Towns was achieved through massive development plans targeting areas farther away from Seoul's urban areas in search for sites available for this new development (30 50km from Seoul's urban centers), and this expansion has accelerated expansion of the SMA.

As these New Towns were developed without relocation of Seoul's employment centers, additional infrastructure including roads had to be constructed to facilitate commuting to and from Seoul, and the main lines were extended to reach suburban areas in the SMA, which further accelerated the SMA expansion.

Such expansion has exacerbated work-residence separation between Seoul and New Towns, and expansion of the main traffic network has also accelerated automobile-dependent commuting. Expansion of the SMA was the result of increased housing price and the government's response to such price increase through the Phase 2 New Town development.

Phase 2 New Town and housing site developments depleted remaining sites available for development in suburban areas, and the government came to implement massive housing supply policies using GB areas as candidate sites for housing projects.

\subsection{Compact Cities and Return to Urban Areas in the Mid-late 2000's}

Expansion of the SMA due to Phase 2 New Town development increased commuting time and cost for residents in the New Towns. This led to growing needs for reducing commuting and the relevant costs to have more leisure time, and the change of demographic structure towards 1 2-member households has caused many people to prefer urban houses with work-residence proximity over houses in suburban New Town areas mostly consisting of large houses.

Faced with such change of preference towards small houses in urban areas, the government announced the Bogeumjari Housing Policy for a variety of groups and individuals requiring houses, in response to massive supply of National Rental Houses which used to be available for only those belonging to 1st 6th income decile. The Bogeumjari Housing Policy provided more houses for sale than rental, to promote home-owning by low-income classes. The government planned to keep the sales prices low by lifting regulations on GB areas (sites available for housing development in urban areas).

Housing sites created in GB areas around Seoul were located within $20 \mathrm{~km}$ from Seoul's urban areas, which means they may result in reorganizing the SMA into a compact city.

The characteristics of Bogeumjari housing sites are as follows: first, they are created as massive towns in areas close to Seoul, raising the residential density and employment density in the

Table 2. Direction of Bogeumjari Housing Policy('09 '18)

\begin{tabular}{|c|c|c|c|}
\hline Characteristic & \multicolumn{3}{|c|}{ Direction } \\
\hline \multirow[b]{2}{*}{$\begin{array}{c}\text { Infill } \\
\text { development }\end{array}$} & Suburban development & $\Rightarrow$ & $\begin{array}{c}\text { Development of areas near } \\
\text { urban areas }\end{array}$ \\
\hline & \multicolumn{3}{|c|}{$\begin{array}{c}\text { Reinforce the city's competitive edge by enhancing } \\
\text { educational/residential functions of the nearby areas, anc } \\
\text { achieve work-residence proximity and prevent emptying } \\
\text { of downtown areas }\end{array}$} \\
\hline \multirow{2}{*}{$\begin{array}{l}\text { User- } \\
\text { customized } \\
\text { supply }\end{array}$} & $\begin{array}{c}\text { Rental } \\
\text { housing-centered }\end{array}$ & $\Rightarrow$ & $\begin{array}{l}\text { Promotion of } \\
\text { self-ownership, } \\
\text { diversification of rental } \\
\text { types }\end{array}$ \\
\hline & \multicolumn{3}{|c|}{$\begin{array}{l}\text { Promotion of home-owning by houseless households, } \\
\text { diversification of rental types to fit consumer } \\
\text { characteristics (income, etc.), pre-reservation system } \\
\text { implemented to consider residents' opinions before } \\
\text { placing offer }\end{array}$} \\
\hline \multirow{2}{*}{$\begin{array}{l}\text { Less burden } \\
\text { on residents }\end{array}$} & \begin{tabular}{|c|} 
Lack of consideration \\
of residents' \\
difficulties
\end{tabular} & $\Rightarrow$ & Affordable, cheap houses \\
\hline & \multicolumn{3}{|c|}{$\begin{array}{l}\text { Supply of low-priced houses through increase of floor } \\
\text { area ratio }(180 \rightarrow 220 \%) \text {, and use of existing } \\
\text { infrastructures, } 15 \% \text { lower than the market price }\end{array}$} \\
\hline
\end{tabular}

Source : Current Issues on Bogeumjari Housing Supply and Direction for Future Development, Urban Information, September 2010. 
SMA; second, they propel urbanization of Seoul as they are located in GB areas on the borders between Seoul and adjacent cities; third, the sites are located in areas with sufficient urban infrastructures, thereby resulting in reduced infrastructure cost compared with New Towns or housing site development districts in suburban areas; fourth, the sites are linked with automobile roads as well as bus and subway lines, which offer better access to Seoul compared with New Towns or housing site development districts in suburban areas; fifth, development of former GB areas will reduce the ratio of green lands in the SMA, even if we consider the fact that the sites are developed in damaged green lands. In addition, the Bogeumjari sites are located around Seoul, which makes the project away to achieve balanced development of deteriorated areas in Seoul urban areas.

The benefits of Bogeumjari housing sites are as follows: first, it prevents urban sprawl and thereby protects natural environment and eco systems in suburban areas; second, they may result in reduced traveling distances and less dependency on automobiles, which may increase use of eco-friendly public transportations and reduce traffic congestion; third, they reduce environmental pollution by decreasing energy consumption and pollutant discharge; fourth, multi-faceted land use in compact urban spatial structures will enhance accessibility to social infrastructures, which will facilitate interaction between different social classes; fifth, they reduce the cost of establishing urban infrastructure and improves economic efficiency of the public transportation system, thereby improving the quality of the relevant services; and lastly, they attract people back to the urban areas, resulting in urban regeneration and revitalization.

\subsection{Urban Regeneration and the 'Era of People's Happiness' in 2014: Urban Regeneration}

Amid informationalization, globalization and aging after the 2000's, the economy and activities of urban residents have been further advanced and diversified. As more residents want to participate in urban planning and development projects, major public projects have come to adopt cooperative planning. Income increase led to elevated cultural needs, especially for high-quality public arts and design within the city's context. The citizens' needs for public provision of parks and green lands is higher than ever.

Socially active career starters, small-sized households and low-income classes want low-priced houses in urban areas to minimize transportation and residential costs. Moreover, while housing sales are stagnant due to recess of the real estate market, increased household debt, coupled with insufficient rental housing supply, have exacerbated residential instability.

In terms of policy, enactment of the Special Act on Urban Regeneration has created the mood for physical improvements including residential environment in existing urban areas as well as social, economic and cultural urban regeneration. While the Bogeumjari policy in the past was aimed at stabilizing housing prices through low sales price, promoting home-owning by houseless, low-income households, achieving social mix by combining houses for sales and houses for rental and relieving burdens borne by project undertakers through profits earned from housing sales, the project faced a series of criticisms for such reasons as suppression of private-led housing supply, decreased competitive edge of the existing Phase 2 New Towns, privatization of development profits, environmental damage due to GB deregulation, exacerbated rental crisis due to rapid increase of potential demands and weakening of the residential safety net due to reduction of rental housing provision.

In 2013, the new government actively countered the criticisms that the Bogeumjari policy distorted the housing market through rapid rent increase, and announced a new housing policy targeting 1 2-member households in downtown areas: the Happiness Housing Policy. happiness housing are supplied further into the downtown area, even compared with National Rental Houses or Bogeumjari houses provided in GB areas, on railroad station sites or unused sites in downtown areas: they were planned to be preferentially supplied to socially active but residentially vulnerable groups, including newly-weds, career starters and university students.

In addition, in consideration of local characteristics, the houses were developed in conjunction with hotel, commercial facilities and other business facilities, and the project was linked with urban regeneration of surrounding old downtowns, so that it may contribute to local revitalization.

The project also involved attracting social enterprises to create jobs, as well as welfare and public facilities to function as forums

Table 3. Difference between Happiness Housing and Public Rental Housing in the Past

\begin{tabular}{l|c}
\hline $\begin{array}{c}\text { Existing Public Rental } \\
\text { Housing }\end{array}$ & \multicolumn{1}{c}{ Happiness Housing } \\
\hline $\begin{array}{l}\text { - Convenience facilities } \\
\text { not included }\end{array}$ & $\begin{array}{l}\text { - Convenience facilities (police, clinic, park, } \\
\text { day care, business incubation, etc.) }\end{array}$ \\
\hline $\begin{array}{l}\text { - Low-income class, } \\
\text { aged citizens, disabled } \\
\text { citizens }\end{array}$ & $\begin{array}{l}\text { - University students, newly-weds and career } \\
\text { starters, excluded from the past public rental } \\
\text { housing policies }\end{array}$ \\
\hline $\begin{array}{l}\text { - Green Belt Areas } \\
\text { - Suburban areas around } \\
\text { cities in the capital area }\end{array}$ & $\begin{array}{l}\text { Supply concentrated in downtown areas } \\
\text { (better transportation/living environment) }\end{array}$ \\
\hline
\end{tabular}


Table 4. Happiness Housing Construction

\begin{tabular}{|c|c|c|}
\hline Construction Plan & $\begin{array}{l}\text { - } 140 \text { thousand houses to be supplied in the nex } \\
\text { - Construction of } 17,6000 \text { rental houses, } 43 \mathrm{~m}^{2}(1 \\
\text { pyeong)-type and } 30 \mathrm{~m}^{2}(9 \text { pyoeng)-type } \\
-7 \text { pilot districts designated in 2014: total area }\end{array}$ & $\begin{array}{l}5 \text { years ('13 '17) (approved projects) } \\
\text { pyeong)-type and } 60 \mathrm{~m}^{2}\left(18 \text { pyeong)-type/ } 24,000 \text { dormitories, } 20 \mathrm{~m}^{2}(6\right. \\
\mathrm{f} 490,000 \mathrm{~m}^{2}, \text { for } 10 \text { thousand houses }\end{array}$ \\
\hline Offer Condition & \multicolumn{2}{|c|}{ - Each district specialized for different groups of residents: newly-weds, university students, etc. } \\
\hline Supply Volume & \multicolumn{2}{|c|}{$\begin{array}{l}-80 \% \text { supplied to newly-weds, university students and career starters/ } 10 \% \text { supplied to under-privileged classes and residentially } \\
\text { vulnerable classes } / 10 \% \text { supplied to those with subscription deposit accounts (differentially supplied in accordance with level } \\
\text { of income) }\end{array}$} \\
\hline $\begin{array}{l}\text { Rent and Rental } \\
\text { Period }\end{array}$ & \multicolumn{2}{|c|}{$\begin{array}{l}\text { - Distinguished from past policies, by considering income level, ability to pay and market rate } \\
\text { - 33 } 50 \% \text { of the market rate / as for dormitories, 32 34\% of the rate in private universities } \\
\text { - Rental period } 30 \text { years }\end{array}$} \\
\hline Implementation & \multicolumn{2}{|c|}{$\begin{array}{l}\text { - Implementation led by } \mathrm{LH} \text { local branches } \\
\text { - Expansion of private participation through public-private partnership projects, etc. }\end{array}$} \\
\hline \multirow{5}{*}{ Related Facilities } & - Social enterprises $\rightarrow$ more jobs for residents & $\begin{array}{l}\text { In government offices and community centers } \rightarrow \text { Used as place of local } \\
\text { harmonization and communication }\end{array}$ \\
\hline & - Young, and lively residential town & $\begin{array}{l}\text { Provided to career starters, university students and newly-weds } \\
\text { - Also supplied to related workers including railroad employees }\end{array}$ \\
\hline & $\begin{array}{l}\text { - Local specialization and multi-functional } \\
\text { commercial complexes }\end{array}$ & $\begin{array}{l}\text { - Rented to residents and nearby residents } \\
\text { - Incentive provided when hiring residents }\end{array}$ \\
\hline & $\begin{array}{l}\text { - Creation as the keypoint for communication, job } \\
\text { and local economy }\end{array}$ & $\begin{array}{l}\text { - Connection of separated areas through railroad } \\
\text { Welfare facilities (day care, play centers, etc.) } \\
\text { Place of communication among residents and local residents } \\
\text { - Sales of local products at outdoor markets, etc. } \\
\text { - Revitalization of town community }\end{array}$ \\
\hline & - Business / employment support centers & $\begin{array}{l}\text { - Attract social enterprises and create jobs } \\
\text { Cultural spaces, including outdoor stages } \\
\text { - Public facilities (police, clinic, resident towns) } \\
\text { - Leisure facilities (outdoor sports, rest areas, etc.) }\end{array}$ \\
\hline
\end{tabular}

for communication between residents. happiness housing are low-priced houses supplied in downtown areas in accordance with the concept of compact city and urban regeneration, and are expected to achieve residential stability for ever-increasing residentially vulnerable people in downtown areas (especially 1 2-member households)

The Happiness Housing Policy represents advancement from the past housing policies, and will serve as momentum for shift into housing policies appropriate for developed countries. This shift involved transition from provision of low-priced houses for sales to low-priced houses for rent, from quantitative supply to qualitative supply, expansion and diversification of classes demanding houses, and transition into user-customized housing policy designed to satisfy their needs.

\subsection{Summary: Assessment of Urban Development Across Changing Housing Supply Policies}

Government-led urban development for housing supply mainly involved construction of large-scale high-rise apartment complexes, to accomplish horizontal expansion and vertical expansion of the urban outskirts at the same time in terms of the shape of urban spaces. National Rental Housing complexes and Bogeumjari Housing sites were created in areas deregulated from GB, and large-scale New Town projects within the city took the form of urban reorganization. Review of the progress of Seoul (SMA)'s evolution (urbanization) reveals a two-fold characteristics: promotion of residential stability, and expansion of urban spaces. Although the national land use system went through major reforms in 2003, and various growth management systems were introduced including the development authorization system, infrastructure conjunction system, land suitability assessment and 2-type district-specific planning, urban areas were left out of such reform drives. In the same year, the government propelled leap-frog development of green lands and GB areas for its 100 Million National Rental Housing Complex Project. Faced with lack of cooperation from local governments, the government enacted the Special Act on Construction of National Rental Housing, etc. at the end of 2004 to streamline the procedures related with project implementation within GB areas. On the other hand, the City of Seoul, implemented its own urban and residential environment organization project 
titled the Gangbuk New Town project, which was aimed at achieving balanced development to relieve the relative deprivation caused by polarization between Gangnam and other areas within the city. The New Town project, however, posed its own problems including lack of feasibility due to large-scale simultaneous development of various areas, and the project itself was stalled by recess of the real estate market. In the end, the project came to focus on large-scale housing supply rather than balanced urban development to revitalize the recessed city, which only resulted in elevation of the land prices. The government and local governments, after cancellation of New Town area designation due to market recess and demand from the residents, the urban spaces of Seoul have been subjected to urban sprawl and deterioration of residential environment in downtown areas due to generation of old, empty and damaged houses and individual uncontrolled developments.

A census conducted in 2010 revealed drastic changes in South Korea's demographic/social structure in the late 2000's: while population increase in metropolitan cities including Seoul slowed down during the period, household types became more diverse along with increase of 1 2-member households. And younger $1 \sim 2$-member households are willing to live in low-priced houses in downtown areas, so as to maintain economic activities at employment centers in downtown areas while saving residential/ transportation costs and commuting time. With the Gangbuk New Town suspended, and housing supply failing to satisfy

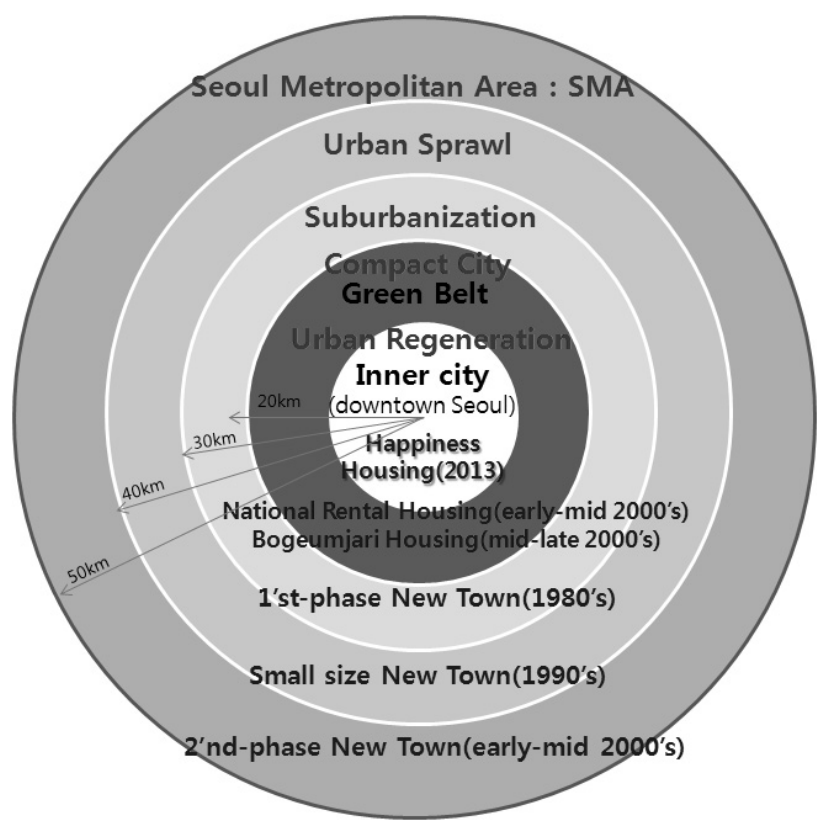

Fig. 3. The Periodic Change of SMA Urban Spaces by Public Housing Policies actual demands, the government the Happiness Housing Policy designed to utilize unused lands including railroad sites and subway station areas, as an answer to the demand for demandtailored housing supply, designed to supply houses where they are needed and revitalize downtown areas. Compared with the Bogeumjari Housing Project represents a case of large-scale public housing supply to areas close to downtown areas, the Happiness Housing Project involves provision of low-priced rental houses even further into the downtown areas. This policy was aimed at providing rental houses to residentially vulnerable young generations, so as to contribute to local economy and revitalize downtown and other areas through active exchange and communication among the younger generations: it has the potential of achieving residential stability and urban regeneration.

\section{Public Housing Policy in response to Changes in Housing Demand and Direction of Urban Development}

\subsection{Direction of Public Housing Policy in response to Changes in Housing Demand}

\subsubsection{Change of Housing Demand due to Change of Demographic and Social Structure}

By reviewing change of demographic and social structure and the relevant factors based on the result of 2010 census, we can

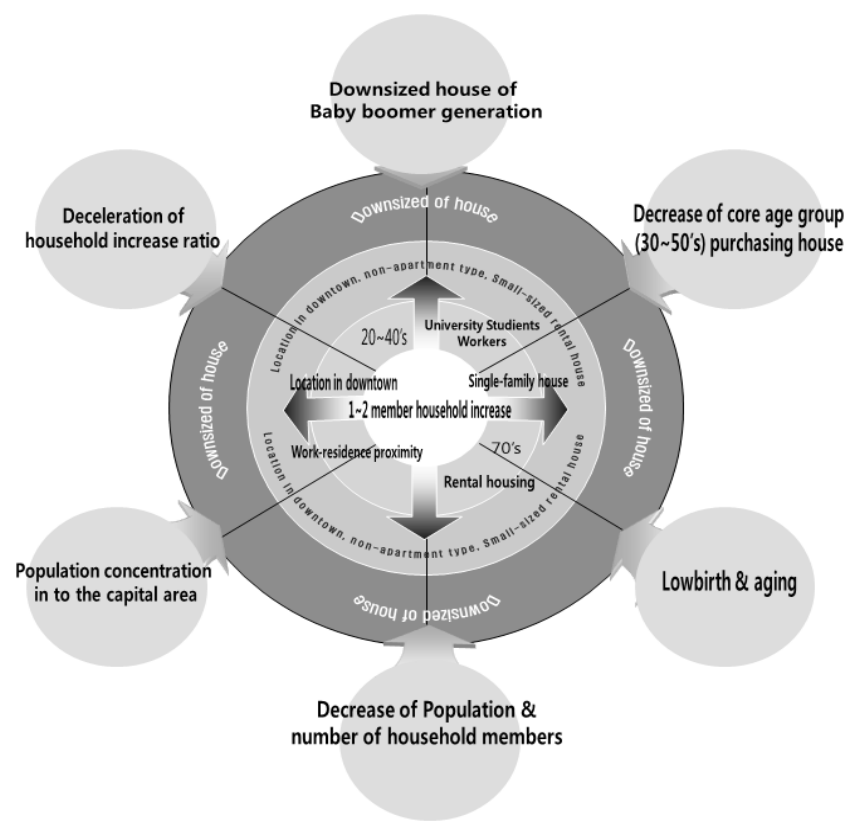

Fig. 4. Downsizing of Houses due to Change of Demographic \& Social Structure, and Characteristics of the Demand Class Source : A Study on Adjustment of Housing Construction Ratios Across Various Housing Sizes in Public Housing Sites, LH, 2011 
estimate the types, scales and locations of houses in the future. Housing demand in the future will be determined by such factors as population decrease, deceleration of household increase, downsizing of houses owned by the baby boomer generation, and lowering of the core age group purchasing houses. In particular, decrease of the average number of household members, increase of 1 2-member households and aging of households are expected to cause downsizing of houses.

As for demographic characteristics, population growth is slowing down and aged population is increasing, while more population flocking into the Seoul Area in terms of location. As the population growth rate has been exceeded by the rate of household division and increase of 1 2-member households in downtown areas, the trend of housing miniaturization is expected to proceed further, thereby increasing the demand for small houses in downtown areas.

1-member households mostly consist of people in their 20 's 40's and 70's, and more of them live in urban areas ('Dong's) than in Eup or Myeon areas. Most 1-member households live in single-family houses, with a considerable percentage of them leased on monthly payment basis. Most 20's people fall into this category, with 30 40's showing higher rate of apartment residence. People in their 60's or older mostly live in self-owned houses, and people in other age groups mostly live in rental houses on monthly payment basis.

Considering concentration of population and households into the SMA, and change of urban space structure due to residence and development in urban areas, it can be expected that 1 2-member households consisting of people in their 20 40's (economically active population, workers) and 70's (aged households) living in small houses will gradually locate themselves in downtown areas or areas closer to the city. The number of 1-member house will continue to increase along with change of demographic/social structure, and these small households will require small-sized houses. Considering the ages (workers in their 20 40's) and residential characteristics (downtown, multi-household, monthly rent) of 1-member households, the housing type suitable for them is low-priced single-family(multi-household) house located in downtown areas to provide work-residence proximity, rented on monthly payment basis. In other words, 1-member households require low-priced small houses located in downtown areas.

\subsubsection{Direction of Public Housing Policy in response to Change of Housing Demand}

Increase of demand for small houses is caused by change of population and household structure, under the premise that the increase of 1 2-member household will change housing demand (According to Statistics Korea, 1 2-member houses will account for more than $50 \%$ of all households. The figure was $39 \%$ in a residence survey conducted in 2010). There are other considerations, however, when establishing housing supply policies to account for increase of 1 2-member households. Generally, different characteristics of small households across different regions should be considered. Specifically, we need to consider their relative unwillingness to purchase new houses, their ability to purchase houses, their preference for work-residence proximity and other requirements (rental houses, future transition to larger houses). Small houses called 'Urban-type Living Houses' provided from the private sector do not meet the demand of the relevant groups due to high rent (500 600 thousand Korean Won per month), and supply of those houses has been somewhat stalled due to profitability issue caused by excessive supply. In terms of residential welfare, the public sector should continue to secure low-priced houses for residentially vulnerable classes, rather than focus on profitability. In addition, in terms of urban space, the housing complexes developed should be of sizes sufficient for inclusion of public facilities and welfare facilities, which will facilitate communication and exchange between residents, thereby preventing slumification of rental housing complexes and achieving desirable urban areas

\subsection{Public Housing Policy for Sustainable Development of Urban Spaces}

With the domestic and foreign housing market in recess after the international financial crisis in 2008 , and housing demand and demand for speculative investment decreased due to provision of low-priced Bogeumjari houses, drastic deregulation for small houses led to revitalization of Urban-type Living Houses in existing urban areas from the private sector. However, these houses posed problems related to residential environment such as lack of convenience facilities including parking spaces and parks, as well as over-population of urban spaces in the future. Therefore, in providing houses in downtown areas, the public sector should take a cautious approach that considers planned and sustainable development of urban spaces. In particular, when providing low-priced small houses, programs for exchange and communication among residents should be adopted to prevent urban slumification and imbalance between housing supply and demand, and such houses should be created to function as 'residential ladder', in consideration of possible housing shift after increase of household 
members and income in the future.

Younger 1 2-member households prefer small houses in railroad station areas with high accessibility to downtown public transportation, showing high satisfaction with reduction of transportation cost rather than higher-quality houses and residential environment. Therefore, in response to increased demand for such houses, the public housing policy should implement changes to support residential stability for younger, residentially vulnerable people while leading improvement of old, deteriorated housing sites or downtown areas which lost the drive for urban regeneration due to cancellation of New Town project.

\subsection{Revitalization of Urban Regeneration through Public Housing Policies}

Urban development in South Korea used to focus on suburban areas and provision of large-scale houses, and development of GB areas closer to downtown did not begin until the 2000's. Not to mention depletion of sites available for development due to extensive development of suburban areas, this was an inevitable choice as those in need of houses preferred low-priced rental houses closer to the downtown areas. Such demand is gradually increasing, with urban spaces in metropolitan cities showing partial deterioration or recess, warranting the need to revitalize local economies and improve efficiency of use of urban lands.

Therefore, as housing supply through urban development has been determining cities' shapes and images, as previously mentioned, we need to induce urban regeneration by supplying houses in downtown areas. The most efficient way to create sustainable cities by regenerating deteriorated urban areas is to induce population flow into downtown areas through housing supply, and promote social, economic and cultural activities.

The government's Happiness Housing Project involves providing low-priced rental houses to younger, residentiallyvulnerable groups in downtown areas in conjunction with urban regeneration. By providing happiness housing, urban regeneration can be accelerated to ensure residential stability of houseless citizens, and attract economically active population into downtown areas. While happiness housing are characterized by shift of urban spaces for housing supply into downtown areas in response to changes of public housing demand, the project is implemented in the form of combined development including facilities and programs designed to prevent possible problems caused by location into downtown areas.

Some Happiness Housing projects were implemented in small scales due to resistance from local residents and thus did not include public facilities and other facilities. Even those projects, however, will have the benefit of gradually regenerating urban areas without excessive confusion, if low-priced houses are provided to younger generations in downtown areas to induce active economic activities.

\section{Revitalization of Urban Regeneration through Happiness Housing Policy as Public Housing Policy}

\subsection{Necessity of Public Housing Supply through Urban Regeneration}

The above sections explored public housing policies and supply through urban development in South Korea, which confirmed that the future direction of urban development requires urban regeneration, and urban regeneration can be induced by supplying houses into downtown areas requiring public houses.

Under the current deterioration of urban areas, the direction of public housing polices and urban development for sustainable development of urban areas need to consider change of housing demand, change of housing location across different stages of urban growth and housing development methods appropriate for the paradigm of each plan. That is, regeneration of existing urban areas in downtown areas requires housing supply in conjunction with urban regeneration.

The project that came closest to the concept described above is the Happiness Housing Project announced under the current Park Geun-hye government.

\subsection{Happiness Housing Project as Public Housing Project Linked with Urban Regeneration}

\subsubsection{Purpose of Happiness Housing Project}

Happiness housing are provided to career starters, newly-weds and university students in downtown areas, as a part of universal housing welfare policy. They can be characterized as usercustomized rental houses in that they function as foothold for younger citizens not capable of achieving residential stability on their own. happiness housing are constructed in downtown areas to achieve work-residence proximity, and they contribute to achieving residential welfare that can be directly felt by lowincome classes, overcoming the limitations of previous rental houses. National Rental Houses and Bogeumjari Houses in the past were constructed in suburban areas including GB areas due to limitations in housing sites and excessive land prices, which inhibited work-residence proximity for low-income classes, and 
Table 5. Comparison of Rental Housing Types

\begin{tabular}{|c|c|c|c|c|}
\hline Items & Public Rental (10 y) & Happiness Housing & National Rental & Permanent Rental \\
\hline Purpose & $\begin{array}{c}\text { To support house-owning by the } \\
\text { houseless households }\end{array}$ & $\begin{array}{l}\text { Residential stability and } \\
\text { improvement of residential } \\
\text { welfare }\end{array}$ & $\begin{array}{l}\text { Residential stability for } \\
\text { low-income class }\end{array}$ & $\begin{array}{l}\text { Residential stability for } \\
\text { lowest-income class }\end{array}$ \\
\hline Location & $\begin{array}{c}\text { Housing Sites in New Towns, } \\
\text { etc. }\end{array}$ & $\begin{array}{l}\text { Sites with work-residence } \\
\text { proximity }\end{array}$ & $\begin{array}{c}\text { Housing districts, including New } \\
\text { Towns }\end{array}$ & Downtown, etc. \\
\hline Target & $\begin{array}{c}\text { Subscriber of Subscription } \\
\text { Deposit }\end{array}$ & $\begin{array}{c}\text { University students, newly-weds } \\
\text { and career starters in 6th decile } \\
\text { or below }\end{array}$ & $\begin{array}{c}\text { Households in the } 4 \text { th decile or } \\
\text { below (*Income: } 70 \% \text { or below } \\
\text { of average income of urban } \\
\text { workers) }\end{array}$ & $\begin{array}{c}\text { Lowest-income classes including } \\
\text { welfare beneficiaries (*Income: } \\
50 \% \text { or below of average income } \\
\text { of urban workers) }\end{array}$ \\
\hline Size & $85 \mathrm{~m}^{2}$ or below & $45 \mathrm{~m}^{2}$ or below & $60 \mathrm{~m}^{2}$ or below & $40 \mathrm{~m}^{2}$ or below \\
\hline Rent & $80 \sim 90 \%$ of the market rate & $60 \sim 80 \%$ of the market rate & $55 \sim 83 \%$ of the market rate & $30 \%$ of the market rate \\
\hline $\begin{array}{l}\text { Period of } \\
\text { Residence }\end{array}$ & $5 \sim 10$ years & $\begin{array}{c}\text { 4 6 years for younger } \\
\text { generations / permanent } \\
\text { residence for industry complex } \\
\text { workers and under-privileged } \\
\text { classes }\end{array}$ & Up to 30 year & Permanent residence \\
\hline
\end{tabular}

exacerbated traffic congestion during rush hours and increased infrastructure cost. While the existing public rental housing policies focused on low-income classes in general, the Happiness Housing Policy represent consideration for residentially vulnerable younger generation in terms of life cycle. The Project can re-initiate downtown housing development which had been suspended due to recess of the real estate market, and result in expansion of long-term public rental housing stock. Happiness Housing may contribute to revitalization of local economy and job creation by supplying business and commercial functions along with rental houses, and attracting social enterprises into the complexes.

\subsubsection{Concept and Supply Characteristics of Happiness Housing Project}

The "Happiness Housing Project" involves 'supplying houses under $45 \mathrm{~m}^{2}$ of various types such as apartment housing, multihousehold housing and multi-family housing to urban areas with population of 500 thousand or more where demand for rental housing is high and public transportation can be easily accessed.' The target sites included railroad sites, national lands around railroad stations, public lands including public facility sites, residential environment improvement project districts, deteriorated residential sites, industrial complexes and lands owned by public corporations that allow for work-residence proximity.

The concept of development involves installation of convenience facilities for the residents through cooperation with related government departments including the Ministry of Health and Welfare, the Ministry of Employment and Labor and Ministry of
Culture, Sports and Tourism. This leads to harmonization and communication with nearby residents, and construction of mixeduse residential complex towns linked with employment and welfare support.

$80 \%$ of the houses are first supplied to younger classes consisting of career starters, university students and newly-weds, and $10 \%$ of the remaining $20 \%$ will be provided to welfare beneficiaries and aged households, respectively. This represents the shift from income-based supply criteria to life cycle-based supply criteria.

Houses will be first supplied to residents selected in accordance with criteria established by the head of the local government, and the rest will be provided to the public through lottery. Thus, a part of housing supply was delegated to local governments, by allowing the head of each local government select $50 \%$ of the residents.

In terms of land usage, happiness housing in residential environment improvement project sites are preferentially provided to existing residents in the area, and those in industrial complex sites are provided mainly to workers. The income criterion is set at $100 \%$ of the average monthly income of workers in urban areas for newly weds ( $120 \%$ in cases where both spouses have income), and $80 \%$ of the average monthly income for career starters. The asset criterion is identical to National Rental Houses for vulnerable class, and the criterion for 10-year rental houses applies to newly weds (as of 2014, prices of automobile / real estate : criterion for National Rental Housing: 25/126 million, criterion for 10-year rental: 28/216 million).

The total rental period is 30 years. The actual residence period 
for residents is 6 years for circulation-induction class (university students, career starters and newly-weds) and 20 years for residential stability support classes (vulnerable class, aged citizens and industrial complex workers). For university students who found employment and career starters who got married, the period is extended to up to 10 years.

Financial support includes provision of $30 \%$ of the construction cost from the government (659 million Korean Won per pyeong $\left(3.30 \mathrm{~m}^{2}\right)$ as of 2014$)$ and $40 \%$ through the National Housing Fund, at the interest rate of $2.7 \%$, which the local governments should repay over 20 years after 20 years of unredeemed period.

The interest rate of construction cost provided through the National Housing Fund is discounted for local governments that choose to implement Happiness Housing project in conjunction with urban regeneration $(2.7 \% \rightarrow 1 \%)$. If the relevant site is included in the urban regeneration project site under the Special Act on Urban Regeneration, the local governments receive additional points for selection and evaluation.

Rents are determined through comprehensive consideration of the project cost, maintenance cost and financial ability of the residents, at $60 \sim 80 \%$ of the surrounding market rate, which are differentiated for different resident classes, so as to achieve residential welfare.

Happiness housing are supplied under authorization of the Ministry of Land, Infrastructure and Transportation under the Special Act on Construction of Public Houses, etc., and the project method, government support and special rules are applied. In particular, the Urban \& Residential Environment Improvement Act, the Special Act on Revitalization and Support of Urban Regeneration, and the Special Act on Promotion of Urban Reorganization apply to conjunction with regeneration of deteriorated residential areas, and the Special Cases Act on Streamlining Authorization/Permission Process for Industrial Complexes, the Act on Industry Location and Development, and the Urban Development Act, apply to conjunction with industrial complex regeneration.

\subsubsection{Implementation of Happiness Housing Project and Related Issues}

The government chose the 'Happiness Housing Project' as one of its national agenda, and the 4.1 Comprehensive Real Estate Countermeasure Plan included the Happiness Housing Project as a way to support universal residential welfare. Later, follow-up measures were taken on April $23^{\text {rd }}$ to determine the concept and direction of the policy, followed by announcement of 7 pilot projects and development plans on May $20^{\text {th }}$, and public hearing for residents on June $12^{\text {th }}$. However, the Happiness Housing Project, which involved creating artificial sites on unused lands and railroad sites for construction of rental houses for houseless low-income citizens in downtown areas, was faced with opposition from numerous local governments and local residents concerned about possibile problems caused by construction of numerous rental houses in each region.

In response to such concerns, the Ministry of Land, Infrastructure and Transportation chose economically active younger classes such as newly-weds, career starters and university students for the project, and tried to create eco-friendly mixed-use residential complex towns including business/commercial functions in conjunction with urban regeneration of the surrounding areas. In addition, the Ministry set the goal of attracting social enterprises to create more jobs, and specializing each district for development into environment, university, communication, sports and multiculturalism districts, so as to minimize the side effect of collective provision of rental houses. Except for the Gajwa District and Oryu District, however, implementation of the project has come to a stand still.

Opposition from the local residents persists even into designation of the project districts after accepting opinions of local governments and residents as much as possible, even reducing number of planned households in 7 pilot sites. Despite the benefit of residential stability for younger generations, the fact that happiness housing are constructed in downtown areas maintained the past image of rental houses, which led to fierce opposition from local residents. More sufficient explanation could have been provided to local residents from the period after the announcement of the

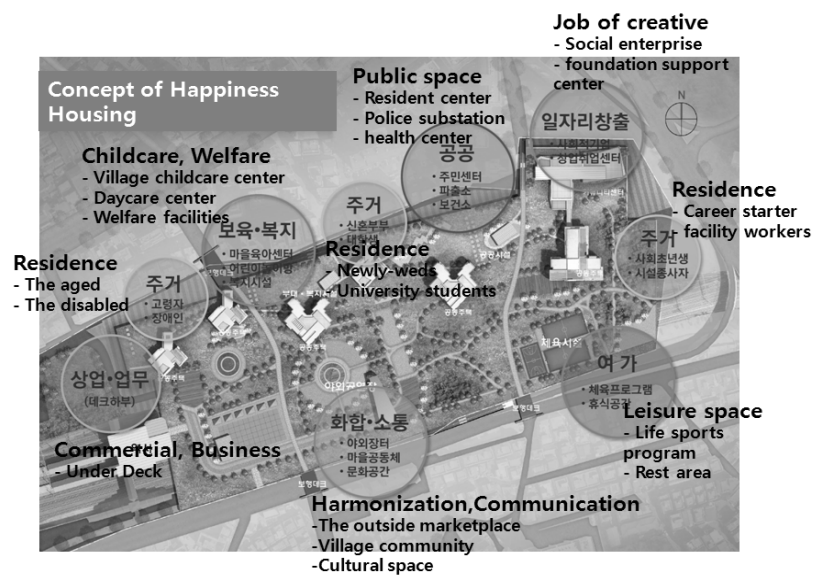

Fig. 5. Concept of Happiness Housing

Source: Ministry of Land, Infrastructure and Transport (http://www. molit.go.kr/happyhouse) 
plant to district designation. Although the Happiness Housing Project was propelled by designation of 5 districts, there are remaining issues such as consultation with local residents during construction.

Two pilot districts have been finalized for the project (Oryu, Gajwa), and construction has already begun in Gajwa District.

In response, the government announced a plan on December $3^{\text {rd }}$ to reasonably adjust public housing supply plan in consideration of opinions from local residents and governments and increased construction expense and lack of appropriate sites, and changed the policy from utilizing limited types such as railroad sites, to utilizing diverse types of lands that suit the purpose of the project.

The supply volume planned for until 2017 was reduced from 200 thousand to 140 thousand, with the 60 thousand discrepancy supplemented with National Rental Houses for residentially vulnerable classes, so as to expand residential welfare for lowincome households and houseless citizens. Despite the volume reduction, housing supply for newly-weds, career starters and university students - who are in dire need for work-residence proximity - will be maintained by raising the ratio of houses provided for them from $60 \%$ to $80 \%$.

In terms of utilizing a variety of lands that satisfy the conditions of work-residence proximity and low rent, 38 thousand houses will be supplied in railroad sites, station areas, public parking lots near stations, water basins and public facility sites, and another 36 thousand houses will be supplied in conjunction with urban regeneration and industrial complex regeneration. Another 39 thousand houses will be supplied in selected sites in good condition near stations or with work-residence proximity among unused lands owned by public corporations ( $\mathrm{LH}, \mathrm{SH})$, where construction has been delayed due to financial reasons and other causes after approval of the housing construction project, and

Table 6. Supply Volume of Happiness Housing (2013 2017)

\begin{tabular}{|c|c|c|c|}
\hline \multicolumn{2}{|c|}{ Items } & Quantity & Description \\
\hline \multicolumn{2}{|c|}{ Public Land } & $\begin{array}{c}38 \\
\text { thousand }\end{array}$ & $\begin{array}{l}\text { Railroad site, station area, public } \\
\text { facility site, etc. }\end{array}$ \\
\hline \multicolumn{2}{|c|}{ Urban Regeneration Site } & $\begin{array}{c}36 \\
\text { thousand }\end{array}$ & $\begin{array}{l}\text { Residential environment improvement } \\
\text { project site, areas excluded from New } \\
\text { Town designation, deteriorated } \\
\text { residential areas, etc. }\end{array}$ \\
\hline \multirow{2}{*}{$\begin{array}{l}\text { Corporation } \\
\text {-owned } \\
\text { Lands }\end{array}$} & $\begin{array}{c}\text { Public } \\
\text { Construction } \\
\text { Site }\end{array}$ & $\begin{array}{c}39 \\
\text { thousand }\end{array}$ & $\begin{array}{l}\text { Station areas or sites with } \\
\text { work-residence proximity owned by } \\
\text { public corporations (LH, SH, etc.) }\end{array}$ \\
\hline & $\begin{array}{l}\text { Civil Sales } \\
\text { Site }\end{array}$ & $\begin{array}{c}27 \\
\text { thousand }\end{array}$ & $\begin{array}{l}\text { Station areas or sites with } \\
\text { work-residence proximity owned by } \\
\text { public corporations (LH, SH, etc.) }\end{array}$ \\
\hline
\end{tabular}

another 27 thousand houses are planned to be provided in lands owned by public corporations, to be sold to the private sector

140 thousand houses will be supplied using public lands, urban regeneration sites and lands owned by public corporations by 2017. Projects for 26 thousand houses will be approved in 2014, and construction for 4 thousand houses will be initiated. 38 thousand houses will be supplied each year from 2015 to 2017 .

\subsection{Diversification of Happiness Housing Project through Urban Regeneration and its Progress}

\subsubsection{Use of Unused National/Public Lands in Downtown Areas}

Effective response to increased housing demand in large cities and continuous provision of happiness housing require use of various national/public lands in downtown areas that satisfy the key conditions for happiness housing : work-residence proximity and low rent. In particular, as the initially planned railroad sites and water basins are not sufficient for securing appropriate housing sites, public parking spaces and unused public facility sites in downtown areas should be actively sought after. Use of national/public lands should be achieved in medium/small scales by purchasing areas adjacent to the national/public lands, rather than massive housing site designation, in order to minimize the effect on surrounding areas and the resultant opposition from local residents.

\subsubsection{Conjunction with Regeneration of Deteriorated Residential Areas}

We need to promote organization of deteriorated, poor residential areas as well as revitalization of local resident, by linking the project with residential environment improvement projects or by using empty, abandoned houses in areas excluded from New Town designation. Downtown slumification and deterioration of residential areas are two problems faced by many existing urban area in South Korea, which means they can be used to attract voluntary participation and project proposals from local governments. In particular, such conjunction may relieve the pressure of price decrease due to cancellation of New Town designation, and revitalize local areas by attracting younger generations into areas with high concentration of low-income aged classes.

\subsubsection{Happiness Housing Supply for Workers in Industrial Complexes}

Industrial complex plans focus on industrial facilities, which 
led to deficiency of houses and convenience facilities for workers therein. Medium/small industrial complexes outside the SMA are experiencing various difficulties caused by long-distance commuting and resultant difficulties in recruiting high-quality workforce. Supply of happiness housing in small-size mixed-use complex towns near industrial complexes or advanced industry complexes in downtown areas will contribute to attracting young, talented workers into the areas

\subsubsection{Use of Unused Lands Owned by Public Corporations}

We need to positively consider the plan to use lands owned by LH, SH and other public development corporations, where construction has been delayed or purchase has not been finalized due to various reasons including financial situation, even after approval of the housing construction project, provided that only the sites with good accessibility to public transportation (including double station areas) located near industrial complexes or universities to secure sufficient residential demand from career starters are selected. Numerical project profit may decrease in the short term by converting unsold site for houses for sales into rental housing sites, it will alleviate uncertainty caused by long-term owning of unsold houses, and inhibit acquisition of additional project sites, resulting in reduced financial burden for project undertakers.

\subsubsection{Progress of Happiness Housing Project Diversification}

As of early June, of all 19 areas including Busan and Incheon $(13,325$ houses), consultation for project implementation has been completed for 9 areas in the capital area $(6,230)$ and 10 areas outside the capital area $(7,095)$. In therms of land usage, the consultation has been completed for 6 public land areas $(3,040), 7$ urban regeneration areas $(5,190)$ and 6 public corporation-owned areas $(5,094)$ : thus, the project is being implemented in a balanced manner. Follow-up procedures will be implemented (district designation, approval of housing project, etc.) after the candidate selection meeting.

\section{Direction of Happiness Housing Project through Conjunction with Urban Regeneration}

\subsection{Issues Related with Happiness Housing Project Linked with Urban Regeneration}

Resolving residential issues experienced by residentially vulnerable younger generations who begin economic activities in downtown areas due to change in demographic and social structure through the Happiness Housing Project is the way to reinforce the social safety net for them. Such implementation will expand the government's interest in the classes of people that have been left out of the government's policies, in keeping with the government's policy for universal residential welfare.

In terms of urban planning, the Project has the significance of functioning as the starting unit for resolution of issues related with urban spaces, such as urban deterioration.

Review of the progress of the Happiness Housing Project so far reveals various issues restricting supply of public rental houses, despite positive assessment of the project as a public housing policy linked with urban regeneration appropriate for the goal of residential stability and urban development.

One of the issues is that the way of implementing the Project should change in order to persuade local residents who oppose the Project (out of concern about decrease of land price, decrease of living quality due to reduction of sports facilities and worsening

Table 7. Happiness Housing Candidate Sites in 2014

\begin{tabular}{|c|c|c|c|}
\hline Site Type & Total & Seoul Area & Outside Seoul Area \\
\hline Total & 13,325 & 6,230 & 7,09 \\
\hline Public Land & 3,040 & $\begin{array}{c}\text { Oryu-dong, Seoul (890) } \\
\text { Yeonsu Station, Incheon (600) } \\
\text { Dongincheon Station, Incheon (250) } \\
\text { Juan Station, Incheon (200) }\end{array}$ & $\begin{array}{l}\text { Dongnae Station, Busan (400) } \\
\text { Gwangju Station, Gwangju (700) }\end{array}$ \\
\hline $\begin{array}{l}\text { Urgan } \\
\text { Regeneration } \\
\text { Site }\end{array}$ & 5,190 & $\begin{array}{l}\text { Yongmaru, Incheon }(1,400) \\
\text { Mini Multi-p[urpose Town, Pocheon (300) }\end{array}$ & $\begin{array}{c}\text { Bukguam-dong, Gwangju (500) } \\
\text { Ami, Busan }(1,200) \\
\text { Techno Industry Complex, Daegu 1,020) } \\
\text { Mini Multi-purpose Town, Jeicheon (420) } \\
\text { Chungju High-Tech Industrial Complex (350) }\end{array}$ \\
\hline $\begin{array}{l}\text { Public } \\
\text { Corporations } \\
\text { Site }\end{array}$ & 5,095 & $\begin{array}{l}\text { Samsong, Goyang }(1,360) \\
\text { Seochan2, Incheon }(630) \\
\text { Segyo, Osan }(600)\end{array}$ & $\begin{array}{c}\text { Daegu Innovative City }(1,100) \\
\text { Asan New Town }(900) \\
\text { Weolsong, Gongju }(505)\end{array}$ \\
\hline
\end{tabular}

Source: Ministry of Land, Infrastructure and Transportation, Happiness Housing Homepage (http://www.molit.go.kr/happyhouse) 
traffic congestion, decrease of green lands, high-density development, flooding caused by basin development, class conflict and slumification, deterioration of educational environment caused by increase of the number of students). In addition, as the local governments also face their own difficulties, the Houses need to be supplied through proposal made by the local governments themselves. The government is sufficiently considering residents' opinions and looking for proposals from local governments on these two issues.

Secondly, more diverse ways need to be reviewed to supply low-priced houses in areas with high land price. Rent increase due to elevation of purchasing/construction cost will undermine the benefit of low-priced houses: therefore, more diverse business models need to be developed. In terms of housing types, various housing types other than apartment houses - construction of which costs a lot of money - to achieve low-priced housing construction that suit the purpose of the Happiness Housing Project.

Lastly, more diverse facilities and programs need to be introduced to prevent slumification caused by collective supply of rental houses in one area. Many people are still expressing concerns over construction of rental houses for low-income classes. The 30-year rental period of happiness housing raises the possibility of slumification compared with the surrounding areas. In the future, the Project needs to be implemented in a way to maximize social mix between different classes, generations and age groups. The soon-to-be-implemented Housing Voucher System need to be used as a way to maximize social mix.

\subsection{Development of Happiness Housing Project Linked with Urban Regeneration}

Urban deterioration, along with changes of demographic / social structure, will increase the demand for low-priced rental houses in downtown areas with work-residence proximity. Therefore, housing supply in downtown areas (Happiness Housing) for residential stability of newly-weds and youths who start their economic activities in downtown areas is the policy that has to be maintained beyond the current government. In this sense, the current initial stage of the project requires sufficient explanation and persuasion as to why we need happiness housing and how they are different from existing rental houses. We need to lead the stakeholders to realize that the Happiness Housing Project represents mixed-use development implemented from the perspective of urban regeneration, combining lands of various usages, and happiness housing not only improves local residential environment, but also accelerates economic revitalization: opinions of local residents should be properly considered at the current planning stage, if not earlier.

In order to minimize the impact on surrounding residential environments and revitalize downtown areas while responding to paradigm shift in the market, the project needs to be implemented under long-term goals, under consideration of housing paradigm shift from producer-centered to consumer-centered, ownership to residence, mass-production of a few types to small-production of various types. The Happiness Housing Project needs to be implemented as convergence project that incorporates job creation and residence/commercial/leisure/culture functions. And the downtown areas need to be revitalized through packing of infrastructure investment in conjunction with financial investment from the government, and the Houses should be supplied in conjunction with urban regeneration project so as to allow for organization of deteriorated residential areas.

Since happiness housing serve as the starting points for urban regeneration in downtown areas, the project needs to be implemented in the form of small-size housing complex development, to minimize negative influence on residential environment. In addition, the current 30-year rental period needs to be shortened as it undermines project feasibility for sustainable housing supply in downtown areas: such reduction will contribute to facilitating Happiness Housing supply through promotion of private participation. Rent needs to be set close to the market rates around the area, in conjunction with the Voucher system designed to reduce residential cost borne by low-income residents.

\section{References}

1. Bae, Kyung-Dong (2006), A Study on the distortion of urban planning \& development of Seoul, Doctorate Dissertation of University of Seoul.

2. Bae, Sun-Seok et al. (2007), Plan for Housing Supply System Adjustment in Response to Housing Supply/Demand, Korea Research Institute for Human Settlements.

3. Byun, Miree et al. (2008), Single Person Household and Urban Policy in Seoul, The Seoul Institute.

4. Cho, Seung-Yeoun et al. (2011), Plan for Revitalization of Bogeumjari Housing Supply in Existing Urban Areas, Land \& Housing Institute.

5. Choi, Eun-Hee et al. (2012), The Effects of Bogumzari Housing in Seoul-metropolitan Area on Urban Structure and Housing Market, Land \& Housing Institute.

6. Hur, Jae-Wan and Eun-Kyung Kim (2009), "Inter-Temporal Comparison of the Characteristics and Backgrounds of Unsold Housings", Real Estate Review, 19(2): 259-278. 
7. Jin, Mee-Youn et al. (2010), Demand Estimation and Mid \& Long-term Prospect for Bogumzari, Ministry of Land, Infrastructure and Transport.

8. Jin, Mee-Youn et al. (2010), A Study on Development of Indicators for Housing Site Supply/Demand in the Seoul Area, Land \& Housing Institute.

9. Kang, Mina (2007), A Study on Estimation of Demand for National Rental Houses, Korea Research Institute for Human Settlements.

10. Kwon Joo-an et al. (2007), Housing Demand of 1-member Household and Housing Supply Revitalization, Korea Housing Institute.

11. Kwon Joo-an et al. (2007), An Analysis on Regional Characteristics of the Jeon-se Market in the Seoul Area, Korea Housing Institute.

12. Kim, Geun-Yong et al. (2009), Korean Housing Supply Programs Based on Demand Analysis, Korea Research Institute for Human Settlements.

13. Kim, Deok-rye et al. (2009), An Impact Analysis on Government Policies for Disposing Unsold Houses and Future Direction of the Policies, Korea Housing Institute.

14. Kim, Deok-rye et al. (2010), An Analysis on Local Housing Markets, Korea Housing Institute.

15. Kim, Ok-Yeon et al. (2012), A Study on the Public Housing Unit Allocation Guideline, Land \& Housing Institute.

16. Kim, Ok-Yeon (2014), LHI Archives, 15.

17. Ministry of Land, Infrastructure and Transport (2010), 2010 Survey on Housing Situation.
18. Ministry of Land, Infrastructure and Transport (2010), Housing Job Guide.

19. Ministry of Land, Infrastructure and Transport (2010), Bogeumjari Housing Job Guide.

20. Ministry of Land, Infrastructure and Transport (2010), Planning Standard for Sustainable New Towns.

21. Ministry of Land, Infrastructure and Transport (2010), Press Release on Happiness Housing.

22. Park, Shin-Young et al. (2011), Characteristics of Housing Demand and Housing Supply Method in the Period of Per Capita Income of 3 40 Thousand Dollars, Land \& Housing Institute.

23. Shin, Eun-Jin and Kun-Hyuck Ahn (2010), "The Factors affecting on the Residential Location Choice of Single Person Households across Income levels: Focused on working people in Seoul", Journal of Korea Planners Association, 45(4): 66 79.

24. Shin, Sang-Young (2010), "A Study on the Spatial Distribution of One Person Households : The Case of Seoul", Journal of Korea Planners Association, 45(4): 81 95.

25. Shin, Sang-Young (2010), Current State and Policy Directions for Quasi-Housing Establishments in Seoul, The Seoul Institute.

26. The Statistics Korea (2010), Household Estimation.

27. Yim, Mi-Sook et al. (2008), A Pilot Study on Housing Development Corresponding to Change in the Population and Society, Land \& Housing Institute. 